$$
\begin{aligned}
& \text { マウスに拈けるヒツジ抗 } \mathrm{N} \text { 型コラゲン血清 } \\
& \text { 投与による腎糸球体変化 }
\end{aligned}
$$

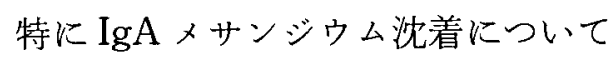

$$
\begin{aligned}
& \text { 益田幸成 } \\
& \text { 日本医科大学第 } 1 \text { 病理学教室（主任：馬杉洋三教授） }
\end{aligned}
$$

\title{
Glomerular change after the administration of anti-Type IV collagen sheep serum in mice Regarding IgA mesangial deposition
}

\author{
Yukinari Masuda \\ Department of Pathology, Nippon Medical School
}

The nephritogenicity of the anti-Type IV collagen sheep serum was investigated by administering it intravenously to $\mathrm{BALB} / \mathrm{c}, \mathrm{C} 3 \mathrm{H}$ and $\mathrm{ddY}$ strain male mice which had previously been treated with sheep IgG and FCA. The animals were sacrified chronologically at 3 days and 1 week up to 10 months. At each interval 2 to 4 mice were sacrified. A control group without any treatment was similarly studied.

An immunofluorescent microscopic study revealed that the sheep IgG was specifically localized in the mesangial region. A similar distribution pattern of the mouse $\mathrm{IgG}$ and $\mathrm{C} 3$ was also confirmed. However, morphological features were seen to be preserved. At $3 \sim 4$ months, accumulation of the mouse $\operatorname{IgA}$ was noted in the mesangial region. This feature is particularly prominent in the ddY mice strain. The amount of IgA deposition was well correlated with the immunochemical determinative amount of IgA in the serum and with the alteration of morphological features.

However, serum IgA antibody activity against sheep IgG in vitro by ELISA showed no close interrelation with the amount of mesangial IgA deposition. Moreover, the renal eluated IgA from the $\mathrm{ddY}$ mice, which disclosed the IgA deposition in the mesangium, showed essentially no antibody activity to the sheep IgG. However, the antibody activity was well maintained in the eluted IgG.

Based on these observations, it is justifiable to assume that the mouse IgA was nonimmunologically trapped in the functionally disturbed mesangium by the locally formed IgG immune complex which is produced by the treatment of anti-Type IV collagen sheep serum to mice. This observation may be useful in clarifying the causative process of human IgA nephropathy.

Key words: mesangial IgA deposition, mesangial functional disturbance, anti-Type IV collagen

\section{緒 言}

IV型コラゲン, ラミニン, ヘパラン硫酸などは腎糸

Correspondence to Yukinari Masuda, Department of Pathology, Nippon Medical School, 1-1-5, Sendagi, Bunkyo-ku, Tokyo, 113 Japan
球体基底膜 (GBM) の主要な構成成分である の研究グループはこれらの glycoproteinのうちIV型 コラゲンをウサギ眼球レンズ被膜より分離, 精製しヒ ッシに免疫して抗体を得た。この抗血清を二，三の実 験動物に静注すると，特に腎では糸球体の GBM より は，むしろメサンジゥム領域を中心に結合することが 
示された，さらにこの抗血清は，モルモットやウサギ に投与することによって増殖性系球体腎炎を惹起する ことをすでに報告3,4)している，しかし，Rothbard ら5) あるいは Shibata ${ }^{6}$ 名報告しているように，マウスや ラットでは GBM 構成成分のうち非コラゲン成分には 催腎炎性が認められるが，コラゲン成分にはないか あってる軽度であるとされている。しかし最近IV型コ ラダンに対する抗血清をマウスに投与し比較的短期観 察にて，蛋白尿の出現および形態学的に腎变化を認め たことが報告7,8)されてきているが，それらには著者ら がすでに報告したウサギやモルモットで観察したよう な強い増殖性系球体腎炎を呈する抂どの変化は認めて いない.

今回，著者はこの報告を確認するために数系のマウ スにヒッジ抗IV型コラゲン血清を投与し, 短期間の観 察のみではなくむしろより長期間の観察に重点をおい て, 処置後最長 10 力月間にわたり形態学的に観察した ところ, 実験開始 $3 \sim 4$ カ月後ごろから高率にメサン ジゥム領域に IgA の沈着を認めるといら興味ある所 見を得たのでここに報告する。

\section{実験材料および方法}

\section{(1) 実験材料}

BALB/cAnCrj, C3H/HeNCrj, お゚よびddY 系マウ ス，雄性 8 週路（体重約 $20 \sim 30 \mathrm{~g}$ ）を使用した。実験 期間中，飼育は通常の方法で自由に食慨および氷を与 えた。

抗IV型コラゲン抗血清は,すでに報告したように Sano らの方法 $(1981)^{99}$ によってウサギ眼球レンズ被 膜にペプシン消化を加え分離，精製したIV型コラゲン をヒッジに対して免疫し, 得ら机たるのを用いた。

（2）方法

各系のマゥスは主として以下に示す $\mathrm{A}, \mathrm{B}, \mathrm{C}$ の 3 群 に分けて行った。すなわち $\mathrm{A}$ 群は, 前処置として 0.1 $\mathrm{mg} /$ 匹 の正常ヒッシ IgGを Freund complete adjuvant (FCA) とともに足蹠に注射し，その 4 日後に $0.5 \mathrm{~m} l /$ 匹のヒッジ抗IV型コラゲン血清を尾静脈より 投与した。 B 群はヒツジ抗IV型コラゲン血清のみを投 与した。C群は前処㯰のみの対照群とした。さらに ddY 系のみには無処置群を D 群として検索を行った。 各系, 各群のマゥスは, 処置直後より最長 10 力月間に わたり, 毎月 1 回適当数ずつ全採血により屠殺し, 直 ちに腎臓を取り出し以下の検索に用いた。
1）形態学的検索

i. 光学顕微鏡的検索

得られた腎臓は $10 \%$ 中性ホルマリンで固定し，パラ フィン包埋, 薄切後, 切片にへマトキシリンェォシン 染色（HE）ならびにPAS 染色を施した。

ii . 免疫組織学的検索

得られた腎組織の一部は蛍光抗体法用にドライアイ スフセトン内冷却 $\mathrm{n}$ 一ヘキサンにて急速凍結し, 使用す るまでー70ㄷ保存した。これらの材料はクラィオス タットにて約 $4 \mu$ の涷結炀片を作製し，FITCラベル 抗マウス IgG, IgM, IgA, 括よびC3 抗体 (MBL, Japan）ならびにFITCラベル抗ヒッジIgG抗体 （Miles Scientific，USA）による鸴光抗体直接法を施 した後, 営光顕微鏡で観察し, 蛍光強度を一, 土, + , 井までの 4 段階に分類し記録した。

iii. 電子顕微鏡的検索

$2.5 \%$ グルールフルデヒド，1\%オスミウム酸によ る二重固定を行い,型ど扣り系列アルコールにて脱水, Epok 包埋後, 灰白色の干渉色を有する超薄切片を作 製し, ウラン, 鉛の二重染色を施し, 日立 H 800 電子 顕微鏡で加速電圧 $75 \mathrm{kV}$ にて観察した。

\section{2）尿検查}

屠殺時膀胱より得た尿を，市販のラブスティックス III（マイルス三共，東京）を使用し蛋白尿㧍よび潜血 の有無について定性的に測定した。

3）腎組織内グロブリン溶出

$\mathrm{ddY}$ 系マ゙ウス主実験 $\mathrm{A}$ 群のヒッシ抗血清投与後 5 カ月目の 10 匹についてその両腎を生食で灌流後,一緒 にしてブレンダーでホモジネートし，遠心分離した。 得られた沈査を十分生食で洗浄し血清成分を除外した 後, $0.1 \mathrm{M}$ クエン酸緩衝液 $(\mathrm{pH} 2.8)$ を加え超音波破 壊を行い $37^{\circ} \mathrm{C} ， 2$ 時間スターラーで擋䢁し，これを遠 心分離後, 上清をリン酸緩衝夜で透析, 次いで濃縮し, 腎溶出液とした ${ }^{10}$.

\section{4） IgA 量の測定}

血清中，腎溶出液中の IgA 量の測定には，Radial immunodiffusion kit (Miles Scientific, USA)を用い て測定した.

5）抗体活性の測定

マウス血清中ょよび腎溶出液中のヒッジIgGに対 するIgG, IgA分画の抗体活性の測定はenzyme linked immunosorbent assey（ELISA）を用いて行った. ELISA Engvall の方法 ${ }^{11}$ に従って行った。すなわ ち，NUNCのELISA 用マイクロプレート (96 wells) 
を用い，抗原として各 wellにヒッジIgG (Miles Scientific, USA)を各 $5 \mu \mathrm{g} / \mathrm{m} l$ になるよらに入れ，2 時間 incubate, 反応後 buffer で洗浄し，1\%BSA 加

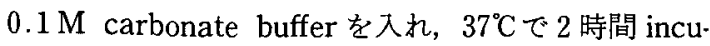
bate し抗原の非結合部位を BSA で block して検体の well への非特異的結合の可能性を除外した後, 希釈し た各血清ならびに腎溶出液を $37^{\circ} \mathrm{C} ， 3$ 時間反応させ た。ささらにラベル抗体として，HRP ラベル抗マウス IgG 打よび IgA (Cappel Lab., USA) にて $37^{\circ} \mathrm{C} ， 1$ 時 間区応後, 洗浄 ᄂ 2.2-azino-di (3-etyl-benzthiazoline sulphonic acid; ABTS) (Zymed Lab., USA)で発色し, Model 2550 EIA Reader(BIO-RAD., USA) の O.D 測定器 (405 nm, filter) 用いて計測乙 た。な拉，抗原，血清, ラベル抗体の希釈に際しては, あらかじめテストした結果から，最適条件のるのを用 いて行った。

\section{結 果}

\section{1. 光題所見}

短期観察として処置直後蛙よび 1 力月目では, ddY, $\mathrm{BALB} / \mathrm{c}, \mathrm{C} 3 \mathrm{H}$ 系のどのマウスにも腎系球体にはメサ ンジゥムの肥厚や細胞増生を示す上うな形態学的変化 は全くみられなかった。しかし $3 〜 4$ カ目ぐらいか ら各系の $\mathrm{A}, \mathrm{B}$ 両群, 特に $\mathrm{ddY}$ 系のマウスの糸球体に はメサンジゥム基質の巣状の拻大が認められるように なり，その一部にはPAS 陽性沈着物の形成ならびに 細胞増生が認められたが，後者は全般的には軽度で あった。

\section{2. 蛍光所見}

3 系マウスそれぞれの群の腎組織に対して, FITC ラベル抗ヒッシ IgG, 抗マゥス IgG, IgM, IgA 扰よび C3 抗体について観察した. ヒッジ IgGは，ヒッジ抗血 清投与群 A 乱よび Bには，どの系にも同様に実験最 終時までメサンジウム優位の営光バターンで観察され た(Photo 1). しかし，各系の抗血清非投与 C 群およ び ddY 無処置 D 群ではすべて陰性であった。 マウス IgGは，ヒッジ抗血清投与群，すなわち A および B 両 群には他の群よりも初期からメサンジゥム優位の蛍光 を示し, 蛍光強度も十一サであり,この傾向は最終まで 持続した (Photo 2). 一方, 血清非投与 C 群および 無処置 D 群にても経時的に IgGの萤光は幾分増加す

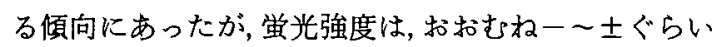
の程度であった。この傾向には系による差異は認めら
れなかった. マウス IgA は, 特に ddY 系には陽性頻度 は高く，ならびに高度沈着例が他の系に比較して高率 に認められた。 らちヒッジ抗血清投与群には, 処置後 3〜4 力月目から多くのマウスで強陽性沈着が, メサ ンジゥム優位に認められた (Photo 3). かつ，この傾 向は前処置を施した A 群のほらがより強く促進され て現われた。一方 IgA の沈着程度と光顕で認められた メサンジゥム基質增生程度には相関傾向が認められた (Photo 4)。 また, ddY系のみには，抗血清非投与群 にも IgA 陽性例は認められたが, 抗血清投与群注ど沈 着は強度でなく, それは $\mathrm{A}$ 群から D 群へ漸次減弱し ていく傾向にあり，しかも D群における強度出現例は 実験開始後 8 カ月目であった. Imai $5^{12}$ と同様に無処 置群 ddY 系マウスは加秢とともに血清中 IgA 量が潮 次增加していく傾向を認めた. BALB/c, C3H 両系の A およびB群では, IgA 沈着の出現頻度は散発的で, からその程度も ddY 系に比べて同程度の例もあるが 相対的に弱い傾向が認められた(Photo 5). 各系各群 の動物個々のメサンジゥム IgA 沈着強度は Fig. 1 に まとめて示した。しかし，すべての系に打いて蛍光で の IgA 強度と IgG 強度との相関は認められなかった。 また IgM の陽性例は高率にみられたが C3は散発的 に陽性で, その程度は両者とも土〜+ぐらいであった。

\section{3. 電顕所見}

$\operatorname{IgA}$ 強度陽性例マウスでは, focal segmental に para- 括よび intra-メサンジゥムに大小不同の電子密 度の高い depositsが認められた。しかしながら上皮下 や内皮下の dense deposits は認められなかった。系球 体基底膜（GBM），内皮細胞，上皮細胞には全例に打 いて変化は認められなかった（Photo 6).

\section{4. $\operatorname{IgA}$ 量}

血清中の IgA 量とメサンジウムの蛍光 $\operatorname{IgA}$ 陽性強 度との間には系による差異がなく，Table 1 に示した ように一般的に血清中の IgA 量が増加している例に 一致してメサンジウムの紗光 $\operatorname{IgA}$ 陽性も強く現われ る傾向を示した。

\section{ELISA 测定}

（1）血清

ヒッジ IgGに対する抗体活性がマウス血清中の IgA 分画にあるか否かを検索した結果, $\mathrm{C}$ 群には軽度, $\mathrm{A}$ 群 では極めてわずかに抗体活性が認められたが，それは 


\begin{tabular}{|c|c|c|c|c|c|c|}
\hline intensity & onth & $1 \sim 2$ & $3 \sim 4$ & $5 \sim 6$ & $7 \sim 8$ & $9 \sim 10$ \\
\hline \multirow{4}{*}{$\mathrm{BALB} / \mathrm{c}$} & - & :૯૯૯ & $\begin{array}{l}9999 \\
4 \times 4\end{array}$ & $\begin{array}{l}090 \\
40 \\
41\end{array}$ & 부붑 & $\Delta \Delta$ \\
\hline & \pm & & $\begin{array}{l}\bullet \bullet \\
\wedge\end{array}$ & $\bullet$ & & $\bullet \bullet \bullet \bullet \bullet$ \\
\hline & + & & 9 & $0^{\circ}$ & & $\bullet$ \\
\hline & $H$ & & & & & \\
\hline \multirow{4}{*}{ C $3 \mathrm{H}$} & - & 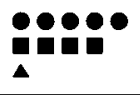 & $\begin{array}{l}\bullet \bullet \bullet \bullet \bullet \bullet \bullet \\
\Delta \wedge 4\end{array}$ & 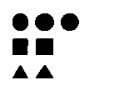 & ш & $\ddot{\bullet}^{\bullet \bullet}$ \\
\hline & \pm & & 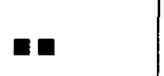 & : & $\because \bullet$ & \\
\hline & + & & & $\bullet$ & & - \\
\hline & H & & & & & \\
\hline \multirow{4}{*}{$\mathrm{dd} \mathrm{Y}$} & - & $\begin{array}{l}90 \\
\Delta \Delta \Delta \Delta \Delta \\
\triangle \triangle \triangle \triangle \triangle\end{array}$ & $\begin{array}{l}\bullet \bullet \\
\Delta \Delta \\
\Delta \Delta \Delta\end{array}$ & $\begin{array}{l}: \\
\Delta \Delta \Delta \Delta \Delta\end{array}$ & $\Delta$ & \\
\hline & \pm & 므 & $\begin{array}{l}\bullet \bullet \bullet \\
\Delta \Delta \Delta \Delta\end{array}$ & $\stackrel{\bullet}{\Delta \Delta \Delta}$ & $\begin{array}{l}\bullet \bullet \bullet \bullet \\
\Delta \Delta \Delta \Delta \Delta \Delta\end{array}$ & $\ddot{\Delta}_{\Delta \Delta \Delta}^{\bullet \bullet}$ \\
\hline & + & & 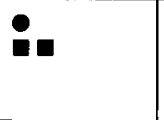 & 부웅 & $\Delta$ & $\underbrace{0}_{\Delta \Delta \Delta}$ \\
\hline & $H$ & & $\because$ & $\bullet \bullet$ & $\bullet$ & \\
\hline
\end{tabular}

Fig. 1 Summarized score represents the intensity of mesangial IgA deposition of each mouse in each experimental strain

The ddY mice show high positive rate of mesangial IgA deposition than other strains and also there is significant acceleration by administration of anti-serum. intensity of mesangial IgA deposition

$-:$ Non, $\pm:$ Mild, + : Moderate, $H:$ Marked

Group : A-, B- $\mathbf{-}, C^{-} \wedge$, D- $\Delta$

Fig. 2 にd 系実験マウスについて示したよらにメ サンジゥム沈着 IgAの強度とは全く相関性を示さな かった. IgGについても同様の傾向が認められ,やはり IgGのメサンジウム沈着とは相関していなかった。

（2）腎溶出液

ddY系マウスで特にA群に高率にメサンジウム
IgA 沈着が認められたため,この群の㬰験開始後 5 カ 月目の陽性例 10 匹のマウス腎を一つにまとめて溶出 を行った。次に溶出液中に IgG, IgA の存在をオクタロ ニー法によって確認したのちELISAにてそれらのた ッシ IgGに対する抗体活性を検索した。その結果を Fig. 3 に示した. すなわち IgG クラスには抗体活性が 


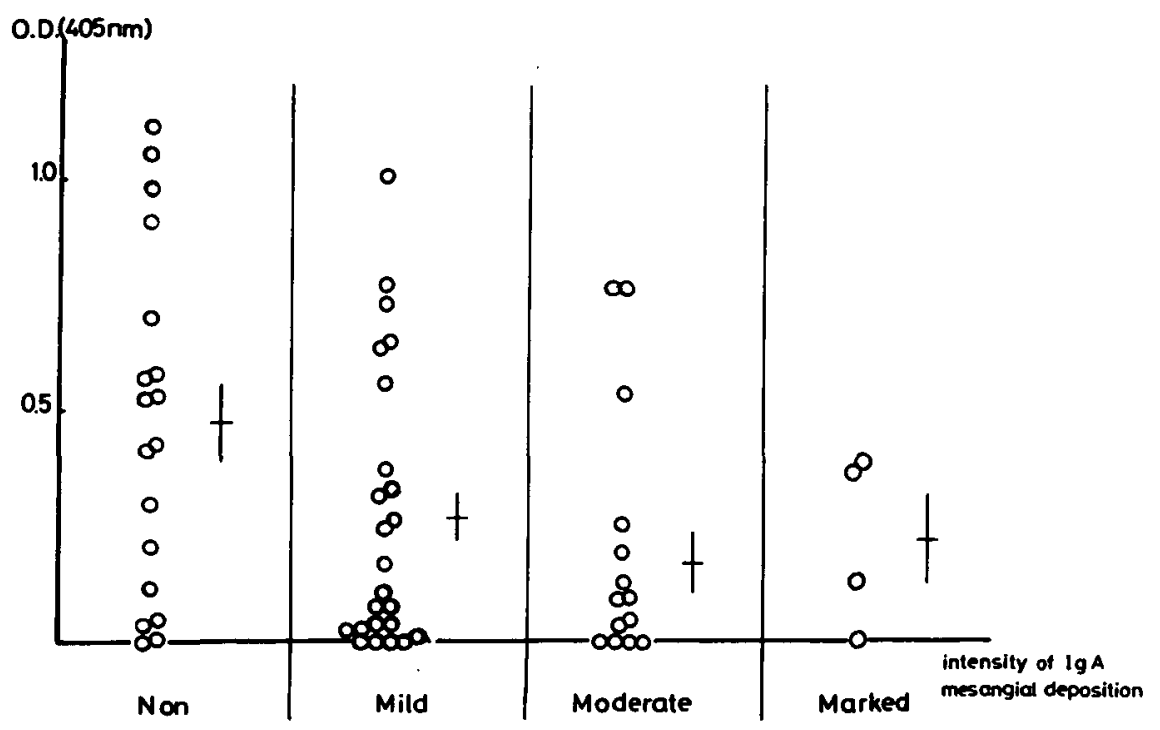

Fig. 2 Relation between the intensity of mesangial IgA deposition and the specific serum IgA antibody activity to sheep IgG measured by ELISA in all ddY mice

$\circ:$ Serum $\times 20,+: M \pm S E M$

\section{$0.0(405 \mathrm{~nm})$}

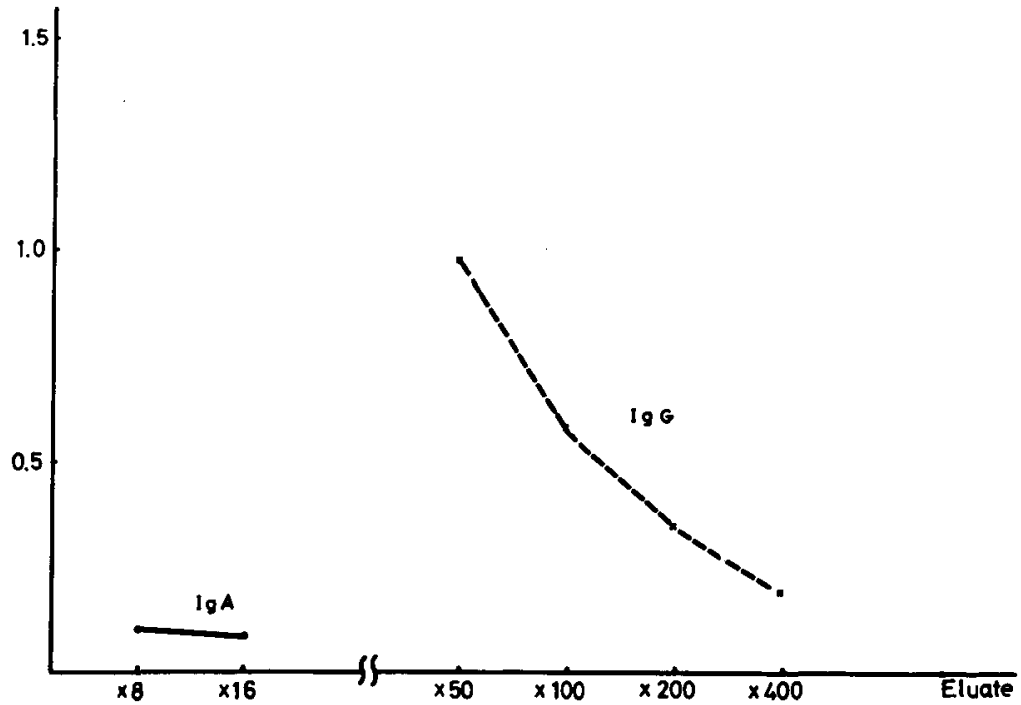

Fig. 3 Specificity of anti-sheep IgG activities of IgA and IgG fraction in eluate from the kidneys of ddY mice of group A in 5th experimental month, measured by ELISA

認められるが，IgA には抗体活性ははとんど認められ なかった。

\section{6. 尿所見}

乐球体形態変化におおむね比例してラブスティック で+〜 \#程度の蛋白尿の排出が認められたが，しかし 
Table 1 Relation between the intensity of mesangial IgA deposition and the average serum level of $\mathrm{IgA}(\mathrm{mg} / \mathrm{d} l)$ of each strain

\begin{tabular}{|c|c|c|c|c|}
\hline & & \multicolumn{3}{|c|}{ strain } \\
\hline & & $\mathrm{BALB} / \mathrm{c}$ & $\mathrm{C} 3 \mathrm{H}$ & ddy \\
\hline \multirow{4}{*}{$\begin{array}{l}\text { intensity of IgA } \\
\text { mes. deposition }\end{array}$} & - & $186.8 \pm 20.2$ & $126.9 \pm 11.2$ & $258.3 \pm 31.8(24)$ \\
\hline & \pm & $740.5 \pm 256.3^{*}(6)$ & $549.3 \pm 110.9^{*}(8)$ & $507.2 \pm 42.6^{*}(32)$ \\
\hline & + & $1613.0 \pm 219.7^{*}(5)$ & $962.0 \pm 608.0^{*}(2)$ & $790.4 \pm 106.5^{*}(13)$ \\
\hline & $H$ & & & $821.5 \pm 144.8^{*}(4)$ \\
\hline
\end{tabular}

concentration of serum IgA $(\mathrm{mg} / \mathrm{d} l)$

*: $\mathrm{p}<0.05,-:$ Non, $\pm:$ Mild, $+:$ Moderate, $+:$ Marked, ( ) : Cases

潜血はすべての例で陰性であった.

\section{考 察}

著者の研究グループはマウスを始めとして種々の実 験動物にヒッジ抗ウサギIV型コラゲン血清をin vitro, in vivoで反応させた。 その結果腎系球体では, 抗体反応は GBM よりは主としてメサンジゥムに強く 起こることを観察している゙．最近この所見はIV型コ ラゲンに対する monoclonal 抗体あるいは polyclonal 抗体による研究報告によって確認されている(13,14)。こ の結果に基づいて今回数系のマウスにヒッジ抗ウサギ IV型コラケ゚ン血清を投与し比較的長期間にわたってそ の腎炎薏起能を観察した。この結果，この実験系には 馬杉腎炎第 I 相の heterologus phase と第 II 相の homologus phase に相当する起炎機序が存在してい るにもかかわらず，モルモットやウサギに認められた ような比較的強い增殖性系球体腎炎像はどの系のマウ スにる認められなかった。しかし $3 \sim 4$ カ月以降にな ると糸球体メサンシ்ム領域に IgAの沈着が認めら れてくることと，この現象は加龄により自然発症的な

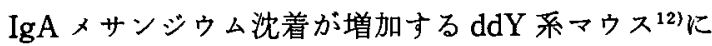
は，それがさらに促進されてみられるといら興味ある 所見を得た。

また長期間観察すると，各系の A, B 両群で $3 〜 4$ カ月目より形態学的には系球体に focal segmental な 腎糸球体メサンジムム基質の巣状の増加と多少の細胞 増生を示す例がみられた。ささらに，これを蛍光観察結 果と対比するとメサンジウムにおけりるマウス IgG 強 度沈着例よりも，むしろ IgA 強度沈着例に高い相関性 を持っていることが明らかとなった。 また血清中の IgA 量を測定すると, この值もメサンジゥム沈着 IgA の蛍光強度に比例して増加しており，それ之高い相関 性を示していることも認められたが，この沈着マウス
IgA がヒッジ IgGに対する抗体活性を有するか否か を，血清中括よびメサンジウムIgA 沈着陽性マウスの 腎溶出液中に括いて ELISA で検索すると，血清中で は前処置群 A，Cに幾分認められるもののそれは IgA メサンジゥム沈着量とは全く相関せず，さらに腎溶出 液中の IgA には抗体活性は全く示されなかった。この 結果この糸球体に沈着したマウス IgAはメサンジゥ ムに先に結合したヒッジ IgG に対する specific な抗 体ではなくて, non-specific に沈着している可能性が

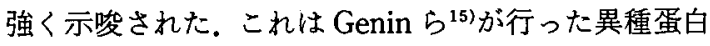
䅅口感作に上る実験的 IgA 腎症でのメサンジゥム沈 着 IgA が特異抗体ではないという検索結果と一致 する。

トレーサーを用いた研究によって腎系球体には，净 化機構と考古られるメサンジゥム流通路の存在するこ とが報告 ${ }^{16 \sim 18)}$ されている. 数多くある報告の内，熱凝 集させたとトIgGをトレーサーとして灌流し，動物の 腎での正常あるいは腎機能異常状態における観察結果 から，サイズの大きい物質はメサンジム基質へのみ 取り込みを認め, から nephrotic animal ではそのメサ ンジウム基質への取り込欢増加し，しかもその物質 のメサンジゥムからの消失が遅延するといわれてい $る^{19,20)}$ 。この nephrotic な状態と今回の実験における 抗血清投与に上る腎変化とは直接には対比でさない が，本実験系では強い增殖性変化は認めないものの入 サンジウムを場としたヒッシ IgG 抗体による heterologus扣よびマウスIgG抗体による homologus phase の in situ 免疫反応が認められた。この結果, メ サンジウムの機能障害を惹起している可能性がある。 これに加党，IgA は他のイムノグロブリンに比し凝集 しやすい性質を持っていることが知られている，以上 よりメサンジゥムに沈着している IgA は機能的障害 を受けたメサンジゥム領域に non-immunological に 
trapされ，長くその場に留まるものと考えられる。こ れにより光顕的に糸球体はfocal segmentalなPAS 陽性沈着物の形成によるメサンジゥム基質の払大と多 少の細胞増生の所見を呈し, さらに電顕的にはparaメサンジゥムに dense deposits 当認められることよ りヒト IgA 腎症との形態的相似性が考えられる。ヒト IgA 腎症は Berger ら ${ }^{211}$ が初めて報告して以来, 各国 から多数の報告がみられ，特に本邦に和いては原発性 慢性糸球体腎炎に占める割合が高い,22,23)，しかしなが らその病因や進展機序の解明には，な颃不明の点が多 く残されている、また, 近年, 病因解明を目的とした 実験的 IgA 腎症の作製の試みは Rifai ら 24)を始めとし て, 種々試みられている。その中でも特に $\operatorname{Ig} A$ が気道, 消化管等と粘膜系の防御機構に深く関係していること から, 異種蛋白である ovalbumin, bovine gamma globulinなどの連続的経口感作により IgA 腎症を誘 発させるといら試みが多くなされており，そのらちに は抗原をメサンジゥムに蛍光抗体法にて証明したとい ら報告すされているが，それの追試による確認はされ ていない25 27). しかしながらメサンジゥム機能障害と いら面からそこに非特異的に IgAの沈着する可能性 について研究された報告は全くない，本実験結果から ヒト IgA 腎症に関しても, その成因との関連性の一つ としてのメサンジム機能障害の問題も今後追究され るべきであると考えられる，最後に今回用いた実験動 物の系でみると，特に ddY 系マウスにメサンジウム IgA 沈着がより促進的に認められる結果となったが, これはヒト IgA腎症に打いてもその発症について何 か遺厷的な因子が関連している可能性を支持する事実 とも考えられる ${ }^{28)}$.

\section{結 論}

ヒツジIV型コラゲン血清を，先にヒッシ IgGと Freund complete adjuvantにて前処置した 8 週蛉の $\mathrm{BALB} / \mathrm{c}, \mathrm{C} 3 \mathrm{H}$ おび ddY 系雄性マウスに静注し，そ の腎について短期間の観察ばかりでなく，ょり長期間 の観察に重点を括いて処置後最長 10 力月間まで毎月 1 回動物を屠殺し，特に糸球体を蛍光抗体法的ならび に通常の形態学的に観察するほか，血清ならびに腎溶 出液を免疫血清学的に検索して以下の結果を得た。

1）処置後,早期から腎系球体の主としてメサンジゥ ム領域にヒッシ IgG, さらにマゥス IgG と C3 の沈着 を示す第 I 相，第II相の免疫反応が生じたが，初期に は糸球体形態変化は少なかった。
2) 処置後，3カ月目ぐらいからマウス $\operatorname{IgADメサ~}$ ンジゥム沈着陽性例が認められ始めた. 特に ddY 系マ ウスにその沈着強度と頻度が高かった。

3）どの系の動物です IgA サンジゥム沈着量は, 血清中の IgA 量と糸球体形態変化の程度に比例して いた。

4）どの系の動物でる血清中のヒツジ IgGに対する $\operatorname{IgA}$ 抗体活性は対応するメサンジウム IgA 沈着量と は全く比例しなかった。

5） IgAメサンジウム沈着陽性の ddY 系マウスから の腎溶出 IgGにはヒッシ IgGに対する抗体活性を認 めたが，溶出 IgA にはそれは全く認められなかった。

以上の結果より，本実験系におけるメサンジゥム沈 着 $\operatorname{IgA}$ は先に局所に形成された IgG 免疫複合物によ り機能的に障害を受けたメサンシゥム領域に, 血清

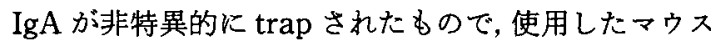
各系のうち加秢とともに血清中 IgAの増加する ddY 系に特に著明に現われたものと考えた。

稿を終えるにあたり，終始本研究にご助力を賜りました日本医 科大学第 1 病理学教空石崎正通博士に深謝致しす寸。 そして同教 室員各位に厚く御礼申し上げます。

なお, 本論文の要旨は, 第 75 回日本病理学会総会(1986 年 4 月) ならびに第 29 回日本腎炡学会総会 (1986 年 11 月) において発表 した.

\section{文 献}

1) Martinez-Hernandez, A. and Amenta, P.S.: The basement membrane in pathology. Lab. Invest., $48,656 \sim 677$, 1983.

2) Laurie, G.W., Leblond, C.P., Inoue, S., Martin, G.R. and Chung, A.: Fine structure of the glomerular basement membrane and immunolocalization of five basement membrane components to the lamina densa (basal lamina) and its extensions in both glomeruli and tubules of the rat kidney. Am. J. Anat., 169, 463 481, 1984.

3) Sano, J.: The induction of glomerular hypercellularity in guinea pigs with anti-basement membrane (type IV) collagen serum. Biomed. Res., 3, 553 560, 1982.

4) Ishizaki, M., Sano, J., Sugisaki, Y., Yamanaka, N., Masugi, Y. and Yajima, G.: Study for type IV collagen; Rabbit glomerulonephritis produced by anti type IV collagen antibody. Jpn. J. Nephrol., 26, 517 518, 1984.

5) Rothbard, S. and Watson, R.F.: Renal glomerular lesions induced by rabbit anti-rat collagen serum in rats prepared with adjuvant. J. Exp. Med., 109, 633 648, 1959.

6) Shibata, S.: Immunologic and non-immunologic aspects of experimental glomerulonephritis. "Biology Chemistry of Basement Membrane" (Kefalides, N.A. ed.) p. 535 559, Academic Press, New York, 1978.

7) Yaar, M., Foidart, J.M., Brown, K.S., Rennard, S.I., Martin, G.R. and Liotta, L.: The goodpasture-like syn- 
drome in mice induced by intravenous injections of antitype IV collagen and anti-laminin antibody. Am. J. Pathol., 107, 79 91, 1982.

8) Wick, G., Muller, P.U. and Timpl, R.: In vivo localization and pathological effects of passively transferred antibodies to type IV collagen and laminin in mice. Clin. Immunol. Immunopathol., 23, 656 665, 1982.

9) Sano, J., Fujiwara, S., Sato, S., Ishizaki, M., Sugisaki, Y., Yajima, G. and Nagai, Y.: AB (type V) and basement membrane (type IV) collagenes in the bovine lung paren. chyma; Electron microscopic localization by the peroxidase-labeled antibody method. Biomed. Res., 2, $20 \sim 29,1981$.

10) Tomino, Y., Endoh, M., Nomoto, Y. and Sakai, H.: Specificity of eluted antibody from renal tissues of patients with IgA nephropathy. Am. J. Kidney Dis., 1, 276 280, 1982.

11) Engvall, E.: Enzyme immunoassay ; ELISA and EMIT. Methods Enzymol., 70, 419 439, 1980.

12) Imai, H., Nakamoto, Y., Asakura, K., Miki, K., Yasuda, T. and Miura, B.A. : Spontaneous glomerular IgA deposition in ddY mice; An animal model of IgA nephritis. Kidney Int., 27, 756 761, 1985.

13) Sakai, L.Y., Engvall, E., Hollister, D.W. and Burgeson, R. E.: Production and characterization of a monoclonal antibody to human type IV collagen. Am. J. Pathol., 108, 310 - 318, 1982.

14) Roll, F.J., Madri, J.A., Albert, J, and Furthmayer, H.: Codistribution of collagen type IV and $\mathrm{AB}_{2}$ in the basement membranes and mesangium of the kidney ; An immunoferritin study of ultrathin frozen sections. J. Cell Biol., 85, 597 616, 1980.

15) Genin, C., Laurent, B., Sabatier, J.C., Colon, S. and Berthoux, F.C.: IgA mesangial deposits in $\mathrm{C} 3 \mathrm{H} / \mathrm{HeJ}$ mice after oral immunization with ferritin or bovine serum albumin. Clin. Exp. Immunol., 63, $385 \sim 394$, 1986 .

16）重松秀一：糸球体の浄化機構。腎と透析, 10, 763～771, 1981.

17) Lee, S. and Vernier, R.L. : Immunoelectron microscopy of the glomerular mesangial uptake and transport of aggregated human albumin in the mouse. Lab. Invest., 42 , $44 \sim 58,1980$.

18) Michael, A.F., Fish, A.J. and Good, R.A.: Glomerular localization and transport of aggregated proteins in mice. Lab. Invest., 17, 14 29, 1967.

19) Mauer, S.M., Fish, A.J., Blau, E.B. and Michael, A.F.: The glomerular mesangium. I. Kinetic studies of macromolecular uptake in normal and nephrotic rats. J. Clin. Invest., 51, 1092 1101, 1972.

20) Mauer, S.M., Fish, A.J., Day, N.K. and Michael, A.F.: The glomerular mesangium. II. Studies of macromolecular uptake in nephrotoxic nephritis in rats. J. Clin. Invest., 53, 431 439, 1974.

21) Berger, J. et Hinglais, N. : Les dd̄pôts intercapillaires d'IgA-IgG. J. Urol. Nephrol. (Paris), 74, 694 695,
1968.

22）富野康日己：IgA腎症の臨床と病理。腎と透析，10， 509 515, 1981

23）坂井紀：IgA 腎炎。“臨床腎荿病檴座第 2 巻”（上田泰，阿 部裕，東條静夫 編)，p. 79 - 91，金原出版，東京， 1981 .

24) Rifai, A., Small, P.A., Teague, P.O. and Ayoub, E.M. Experimental IgA nephropathy. J. Exp. Med., 150, 1161 1173, 1979 .

25) Isaacs, K., Miller, F. and Lane, B. : Experimental model for IgA nephropathy. Clin. Immunol. Immunopathol., 20, 419 426, 1981.

26) Emancipator, S.N., Gallo, G.R. and Lamm, M.E. : Experimental IgA nephropathy induced by oral immunization. J. Exp. Med., 157, 572 582, 1983 .

27) Sato, M., Ideura, T. and Koshikawa, S.: Experimental IgA nephropathy in mice. Lab. Invest., 54, 377 384, 1986.

28) Sakai, H., Nomoto, Y., Arimori, S., Komori, K., Inoue, $H$. and Tsuji, K.: Increase of IgA-bearing peripheral blood lymphocytes in families of patients with IgA nephropathy. Am. J. Clin. Pathol., 74, 452 456, 1979.

\section{Legends}

Photo 1 Immunofluorescent micrograph of glomerulus from a ddY mouse treated with anti-type IV collagen sheep serum with pretreatment of sheep IgG and FCA (group A) at the 4th experimental week.

Stained with rabbit anti-sheep IgG. It distrib. utes mainly in the mesangial area. $\times 600$

Photo 2 Immunofluorescent micrograph of glomerulus from a ddY mouse of group $A$ at the 4th exp. week.

Stained with rabbit anti-mouse IgG. $\times 600$

Photo 3 Immunofluorescent micrograph of glomerulus from a ddY mouse of group $A$ at the 4th exp. month stained with rabbit anti-mouse $\operatorname{IgA}$, shows positive stain in the mesangial area. $\times 600$

Photo 4 Light micrograph of the same sample as in photo 3 .

Note increased glomerular mesangial matrix and mild cell proliferation. PAS stain $\times 600$

Photo 5 Immunofluorescent micrograph of glomerulus from a $\mathrm{C} 3 \mathrm{H}$ mouse of group $\mathrm{A}$ at the 6th exp. month stained with rabbit anti-mouse IgA. It is also noted in the mesangial area. $\times 600$

Photo 6 Electron micrograph of a portion of a glomerulus from a ddY mouse of group $A$ at the 6 th exp. month.

Various electron dense deposits in the paraand intra-mesangium are shown. Uranyl acetate and lead citrate atain. $\times 5,200$

（受付：1987年 6 月 25 日） 
Plate (1)
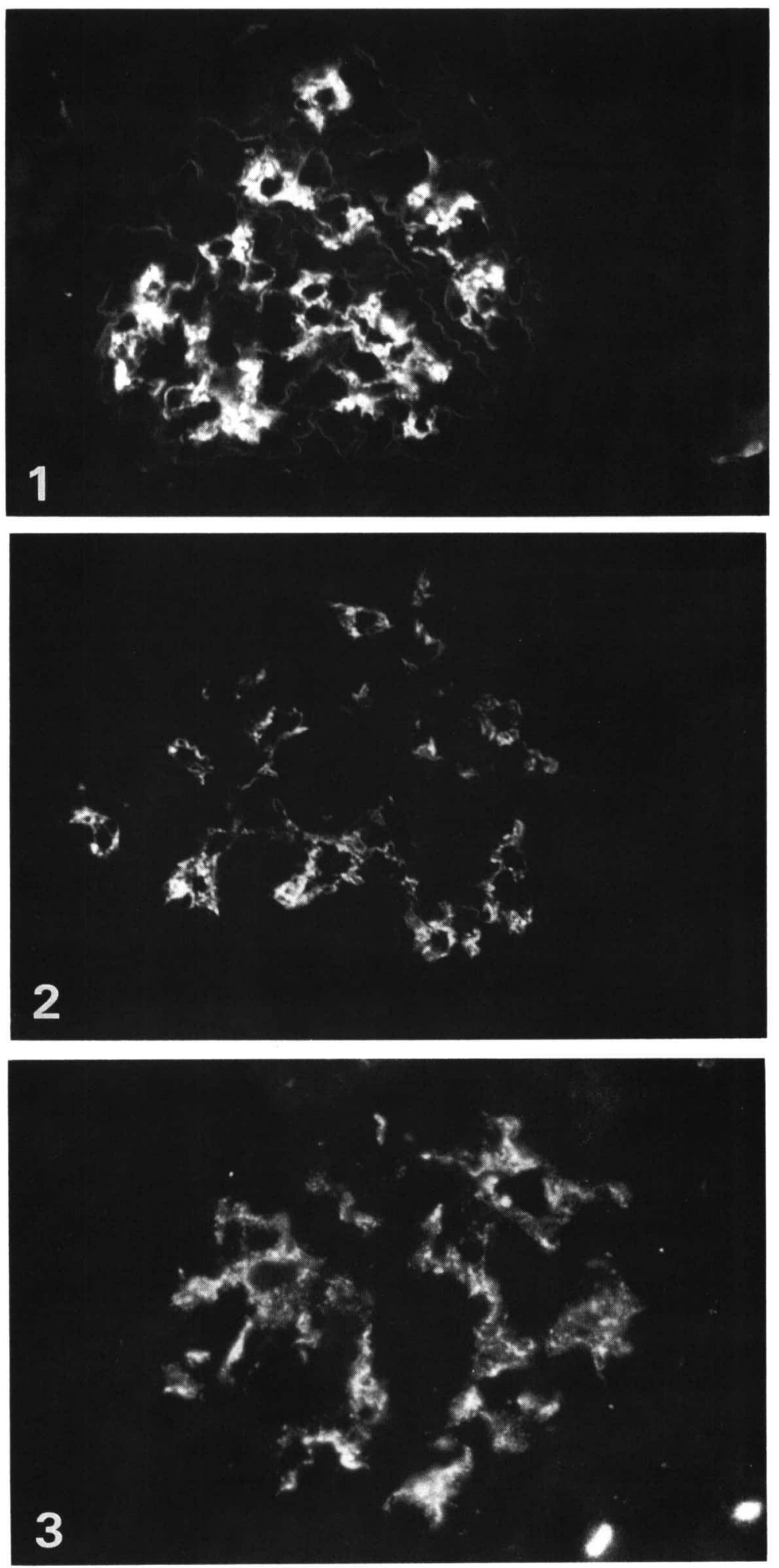
Plate (2)
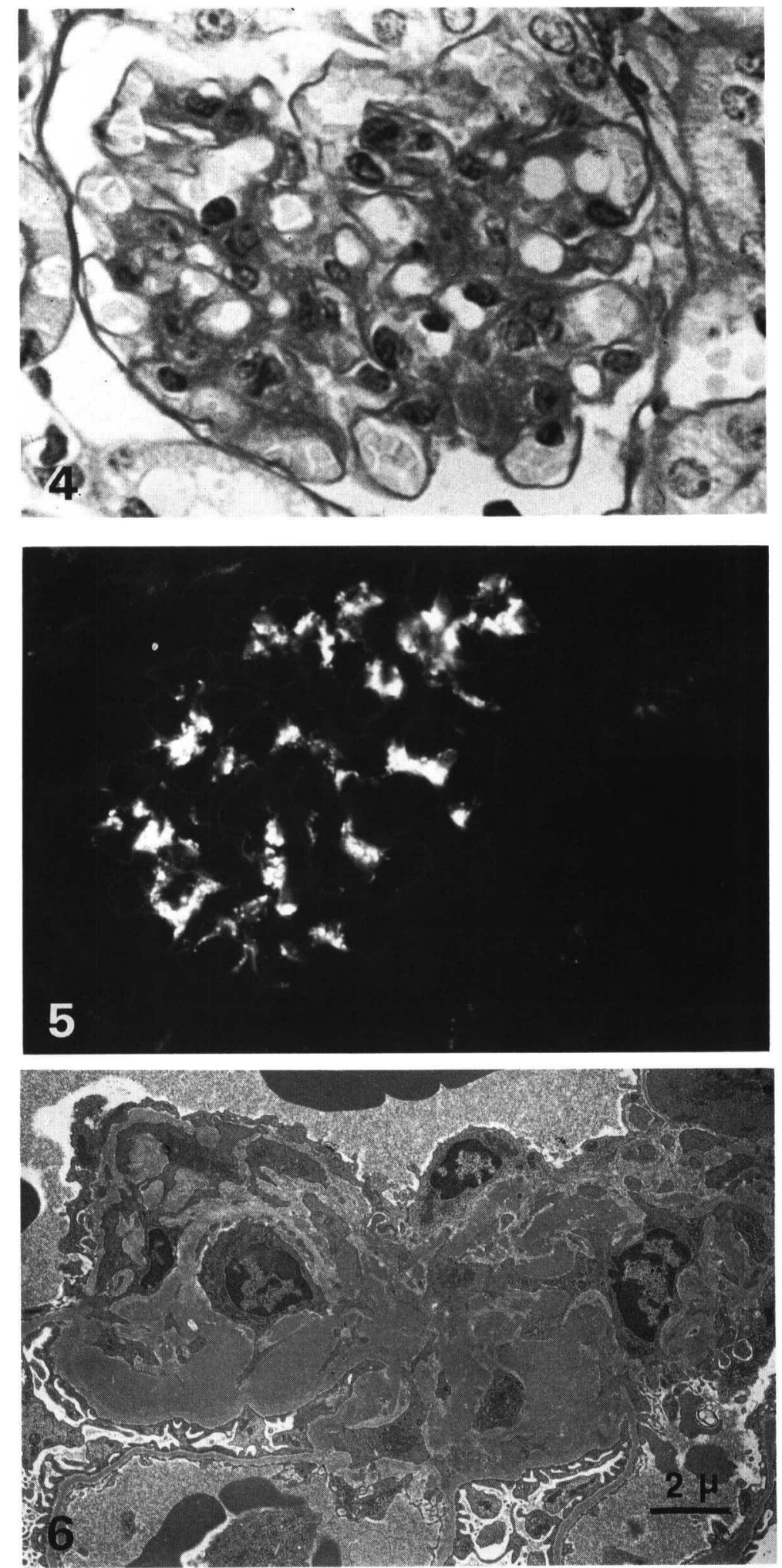